\title{
Converting and Disputing the Role of Traditional Cultural Institutions in Cameroon's Cross River Basin, 1916-1961
}

\author{
Henry Kam Kah
}

\begin{abstract}
This article probes the British and missionary misinterpretation and presentation of the role of Ekpe, Nfam, and Obasinjom cultural institutions as irrelevant in the governance of people of the Cross River Basin of Cameroon. The British colonial enterprise in the area was sustained on a seemingly conscious yet uncritical effort to label these institutions as mainly ceremonial and food consuming in nature. This impression notwithstanding, these institutions remained popular and continuously spread into the nooks and crannies of the Cross River Basin of Cameroon and beyond.
\end{abstract}

Keywords cultural institutions, misrepresentation, British colonialism, Cross River, Cameroon

\section{Introduction}

This study examines the British and missionary (mis)interpretation and/or (mis) representation of the role of Ekpe, Nfam, and Obasinjom cultural institutions as irrelevant in governing and regulating the people of the Cross River Basin of Cameroon and, by extension, Nigeria. The area of study was initially colonized by Germany on July 14,1884 . It was officially placed under British administration as a mandated territory of the League of Nations in 1922, following the defeat of Germany in World War I. A lot has been written about European and Christian missionaries in Africa during the colonial era, but the subject of misrepresentation and misinterpretation of African institutions continues to be debated in African historiography. Evidence points to calculated attempts by the colonial administration, acting in tandem with the missionaries, in many instances to denigrate African institutions. Yet, some of these institutions were solicited in handling difficult judicial matters in the Native Courts by the British in many parts of Africa including the Cross River region of Cameroon and 
Nigeria.

Cameroon is officially a bilingual country where English and French are the languages of business and administration. Apart from these two languages used for official government business, the country boasts over 280 national languages and a national lingua franca, Pidgin English. It is situated next to the resource-rich Gulf of Guinea and straddles the West and Central Africa regions. When the Germans were defeated in Cameroon in 1916, Britain and France tried a condominium. But it failed because of differences over territorial control and authority. Both countries therefore agreed to an unequal partition of former German Kamerun. France took control of four-fifths of the territory and Britain the remaining one-fifth. Between 1922 and 1961, when British Southern Cameroons gained independence through reunification with the Cameroun Republic (former French Cameroon), it was governed as an integral part of the British colony of Nigeria. The administrative policies of Germany, Britain, and France in the territory negatively impacted the activities of cultural institutions, but did not erase them from existence. Rather, some of these institutions like Ekpe (Efik), Mgbe/Ngbe (Ejagham), or Nyankpe/Nyamkpe (Banyang) spread beyond their sites of origin to other hinterland communities.

The negative policies notwithstanding, cultural institutions have continuously played an important role in the socio-cultural, economic, and political life of many Cameroonian ethnic groups in general and those of the Cross River region in particular. Cultural institutions and festivals of renown in Cameroon include the Kwifon, Nwerong, Ngiri, Ngumba, Ngoun, and Lela among others in the grassfields of Cameroon, and Ahon, Nganya, Ngondo, Muankum, and Ekpe in the forest region. Their continuous relevance to this day attests to their importance in regulating the excesses of their communities, as sometimes recognized and encouraged by the government. Many Christians who previously opposed them are today members, although the stigma persists in some communities.

\section{Basis of Investigation}

Translation has been described as a cognitive procedure and viewed as a predominantly social, cultural, political, ethical, and ideology dominated affair. In the process of translation, representations of other cultures are constructed (House 2015). This representation has formed and/or deformed cultural realities through systems and the master discourses of representing the foreign or other for the local or self. Translation at times involves manipulation and subversion of cultural goods (Faiq 2008, 32). This deliberate (mis)translation, manipulation, and (mis)representation is succinctly captured by Lhoussain Simour (2014, xi) when describing the American and European representation of the Muslim world. He opines that "citizens of Western nations almost uniformly believed only 
those representations to be one truth about 'The East' as supposedly unchanging, antiquated, violent, sexualized, and decadent place." He further contends that "misrepresentation has been a major trait of the West's portrayal of the Other in the archives of Western History ... Such images are still promoting stereotypes that are prevalent in a post-colonial era" (ibid., 12).

Similarly, Faiq $(2008,40)$ examines the misrepresentation of words in the prevailing master discourse generated by the Western world. He argues that the word "jihad" has been commonly adapted in English to mean "holy war," when to Muslims it means much more than just holy war. It literally means "striving" and generally appears as part of the expression "jihad fi sabil illah," that is, "striving on the path of God." When the West reduces it to holy war without the accompanying broader meaning, it completely conveys a different message to the Western audience and other people who then see nothing good in Muslims. In the nineteenth century, the British colonial agenda translated indigenous texts only as part of the larger enterprise of imperialism (Abu-Mahfouz 2008, 1). In Africa, they became involved in the idea of "Imperial Monarchy" much more than they did in India during the colonial era. Ranger $(1992,212)$ opines that "the 'theology' of an omniscient, omnipotent and omnipresent monarchy became almost the sole ingredient of imperial ideology as it was presented to Africans." Peoples' attitudes toward others have often been shaped by their perceptions of the peoples' past which at times is far removed from reality. In this connection, many people outside of the African continent, and some within the continent, have very strange ideas about the continent's past (Connah 2003,26) as depicted by the administrators and missionaries who worked in Africa during the colonial period. These ideas are not fully representative of the African past.

The history of translation is the history not only of literary innovation but also of the shaping power of one culture upon another (Venuti 1995, vii). This article draws its inspiration from this notion. The British translated indigenous texts in India, for example, as a larger imperial venture of subjugation. The colonial administrative officers and the missionaries used their presence and influence to shape, represent, and mis-translate what the indigenous cultural institutions had represented to their people. In the Cross River region of Cameroon, as in Nigeria, a conscious, deliberate, and miscalculated representation of cultural institutions was the norm. This was to prevent them from frustrating the greedy colonial agenda of subjugation and exploitation. In what this article describes as "historical (mis)translation," the focus is on a deliberate cultural approach of a master discourse to denigrate, weaken, render irrelevant, and destroy other cultural institutions for political and economic capital. 


\section{Importance of Cultural Institutions}

Cultural institutions in Africa served several purposes and remained important to their people. The British colonial administration at the beginning relied on such institutions like the Kwifon and Ekpe for advice. These were regulatory societies that served as legislatures for traditional governance or administration. As the legislative arm of the traditional government, both Kwifon and Ekpe had the power and ability to regulate the power of the king (Dekorne 2012, 28). The Germans used the Ekpe, for example, in facilitating governance within the ethnic groups of the Cross River region of Cameroon. Through the highly respected Ekpe, the Germans instructed the people of the Cross River region on governance (Enonchong n.d.). Their relevance transcended the socio-cultural, economic, and political spheres. The Kwifon regulatory society in the North West Region of Cameroon was and remains a dignifying and royal institution. In the Kom Kingdom, for instance, it was the executive arm of the government of the Fon (Chief) and exercised advisory, judicial, and ritual functions. Kwifon retainers communicated important messages from the Fon to the people. The institution also regulated the economic affairs of the fondom such as the inauguration of crop harvests and market activities (De Vries 1998, 10-11). In the Laimbwe villages of Cameroon, the Kwifon (Kuiifuai) maintained justice, peace, progress, and stability (Kah 2015, 163).

In Oku, Kwifon was the traditional government of the land and exercised considerable control over the medicines that were administered to the population for good health. Its masquerade performers pursued and punished witches and all other offenders of the customs and traditions of the people. It still dispenses justice today and metes out social sanctions against violators of tradition and social mores. This is done side by side with the modern courts, government institutions, and the gendarmerie, a paramilitary force common in French speaking African countries. Punishment meted on defaulters included restitution, fines, and banishment from public ceremonies or the fondom (Bartelt 2006, 149). Similarly, the Nwerong in the Nso kingdom was more or less a fraternity that enforced policy. It also provided messengers to the Fon, enforced decisions of the Fon-in-Council, and punished criminals and witches on the orders of the Fon, among other functions (Chilver and Kaberry 1960, 2-3). Another cultural institution in Nso, the Manjong, was a military club which provided the basis for military and hunting organization within the kingdom. The Manjong also assisted in the reconstruction of compounds destroyed by fire. The institution also fined members for disobedience and breach of rules (ibid.).

In Cameroon's coastal regions, several cultural institutions also served important purposes. The Ngondo traditional and religious institution of the Duala of the Wouri Estuary is built around peace, development, and social stability among the Duala and Sawa speaking people. This is obtained from aquatic 
spirits (Mokake 2012). Although ritual performances like the Ngondo have been politicized since the re-introduction of multiparty politics in the 1990s in Cameroon, they remain institutions of pride, peace, and unity for the Duala and Cameroonians. Despite the hostility of the French towards the Ngondo during the colonial period, it continues to serve as a link between the Duala of the past and present (Austen 1992, 286). At its inception in early 1800s, Ngondo was a judicial and governing body and was presided over by major Duala chiefs. It passed judgment on trade disputes in the inland market places (ibid., 287) similar to what the Ekpe did in the Cross River Basin.

Cultural institutions from other parts of Africa served similar functions to those in Cameroon. The Poro and Sande of the Mende and Temne chiefdoms in Sierra Leone and Liberia and the Ogboni, Agemo, and Egungun of the Yoruba of Western Nigeria carried out ritual ceremonies and diplomatic missions for good neighborliness and peaceful co-existence. These institutions also served as guardians and policemen of public morality in their chiefdoms. As local tribunals, they settled disputes, litigations, and other matters among their people, and created a congenial environment for socio-economic activities to thrive. Similar to the practices of the Cross River region, some of these institutions hunted witches and wizards to rid society of these unwanted elements (Kah 2011, 56). The Atam masquerades or mask performers (mostly men) among the Bakor of South East Nigeria performed several functions, including the imposition of fines on offenders, control of palm oil production for export, regulation of harvesting fruits, and protection of forest reserves from destruction (Majuk 2011, 66-73). Ganyi et al. (2013, 55-6) observe that the Atam facilitated the circulation of information through which cherished cultural values were preserved. It was a contribution of ancestors to the legitimization of the ethical code of the community. It also purified and enhanced a cordial and crisis free communal existence by stigmatizing stealing, sexual immorality, greed, and intolerance. In spite of the important role of these cultural institutions in Africa, the colonial administrators and missionaries painted them in a different light.

\section{Cultural Institutions: Administrative and Missionary Depiction}

In many parts of Africa, Latin America, and Asia, European colonial officials and missionaries ascribed to cultural institutions certain attributes which smacked of ignorance, or deliberately attempted to debase them and super-impose other structures in their place. Many of these institutions still suffer from this stigma of colonial interpretation. The mistranslations and misrepresentations were resisted by many, while others collaborated with the colonial administrations and missionary societies. The colonial administrations, in tandem with some missionary societies, deliberately or not, offered bleak images of cultural 
institutions in Africa with the intention of replacing them with their own institutions. A lot of what they said about these institutions was based on their own imagination.

At the beginning, British colonial officials in many parts of Africa sought to understand and work with the cultural institutions they met without destabilizing them. The colonial administrators professed that indigenous systems of government would be maintained to manage local affairs, but they were to remain subordinate to the colonial administration (De Vries 1998, 21). Chiefs who were pillars of local administration in their villages were co-opted into the colonial state to serve various purposes (Mbu 2013, 14). Through this, the British administrators consciously or unconsciously began to invent African traditions to serve their imperial interests. Ranger $(1992,212)$ contends that "their own respect for 'tradition' disposed them to look with favor upon what they took to be traditional Africa. They set about to codify and promulgate these traditions, thereby transforming flexible custom into hard prescription." This, in a way, was an invention or re-invention of tradition in Africa. This might not have been done with the same degree of temerity in all of British colonial Africa, but most colonial administrators performed their assigned functions with this in mind. Afigbo $(1985,489)$ aptly puts it this way: "Under indirect rule, indigenous institutions and rulers were expected to serve as media for introducing reform in measured doses and in ways acceptable to the colonial authority." Similarly, Crowder (1993, 81-82) argues that although the British administrators claimed that they were advisers to the Native Authorities (NAs), they actually more or less directly supervised many aspects of the conduct of these NAs.

The pretense that characterized British colonial administrators in their functions is captured in Talbot's book on South Eastern Nigeria and Cameroon. In the preface to the book, Talbot asserts that "this book claims nothing, save that it strives to tell the story of a little-known people from a stand point as near as possible to their own" (Talbot 1912, vii). Yet, throughout this book, Talbot's description of the people and their institutions is buried in cultural misinformation, and thus the book provides readers with misrepresentations and mistranslations of what their values and functions truly represented. In one of such description of the Ekpe institution he asserts:

The many-sided character of Egbo [Ekpe] may be judged from the immense powers which it has arrogated to itself in almost every direction. Under native rule it usurped practically all functions of government, made trade almost impossible for nonmembers, and exercised a deep influence on the religious and mystic side of the nation (ibid., 39).

A close examination of the description of the Ekpe society in Talbot's book does not show that he was "as near as possible" to the native view of this 
institution. To assert that Ekpe arrogated to itself functions shows the degree of ignorance or cultural chauvinism in Talbot's account. The British, like the Germans, met an existing institution which had legislative and executive power over the peace and stability of its communities. It even explains why European merchants were initiated into it and/or used it to defend their trading interests. If the Ekpe did not secure effective commercial activities, how would the merchants from Europe have succeeded in their business ventures? Did this mean arrogating to itself immense powers? Talbot also argues that the Ekpe usurped practically all functions of government. The use of the word "usurp" is a misnomer because it was known by members of the society that Ekpe was a governing institution with religious and secular functions. It therefore did not seize governance, but performed what were rightfully and acceptably its own functions. These are misrepresentations that Talbot had set out to avoid, but unfortunately did not. Mungwini laments such reconstruction and reproduction of African social realities by colonial anthropologists in these words:

Colonial anthropologists construed everything in colonial Africa to be 'primitive,' 'savage,' 'pre-logical' and 'traditional.' The colony was projected and disavowed as anachronistic. The effects of this negative characterisation of the African continue to manifest themselves in diverse forms, including skepticism towards indigenous institutions and forms of knowing (Mungwini 2011,2).

Like Talbot, Charles Partridge, a British colonial administrator in South Eastern Nigeria, in the introduction to his book on the Cross River Natives, said he had been advised by many of his seniors in the profession to "study the native from the native point of view" (Partridge 1905, vii). In spite of this lesson, Partridge, like Talbot, soon began to judge the people and their institutions. This was the mentality of most colonial officials, even if they had the best of intentions to present a balanced view of the customs and traditions of the people they governed. He said of the people of the Obubura Hill District that:

The natives of Obubura Hill district are all pagans. The dictionary defines paganism as 'the worship of false gods,' meaning, presumably, the recognition of spirits that, owing to former geographical difficulties, do not happen to have found their way into our own calendar of canonised worthies (ibid., 279).

When Partridge described the Obubura people as "pagans," this was a misrepresentation of who these people really were in daily life. The Obubura worshipped the Supreme Being in a way that was dissimilar to the British way of worship. Partridge's description was buried in the master discourses of superiority and inferiority. This description was buried in cultural stereotypes which did not reflect reality. Partridge did not effectively practice the schooling of his seniors to study the "natives from the native point of view." Had he practiced this 
lesson in reality, he would not have said that the people of Obubura Hill District were pagans. The negative impression about the Obubura people might have contributed to the decision to undermine their indigenous institutions.

Instability in Africa was exacerbated by European contact with the people. This was accentuated by European administrators and missionaries. They sought to justify the kind of new order which they brought to Africa (Cadwell 1985, 472). Colonial administrators were hostile towards certain religious practices and did everything they could to abolish them. They also suppressed some cults, but, in some areas like in German East Africa, the well-known and documented Maji Maji resisted colonial rule during the first decade of the twentieth century. Similarly, the Mwari in Southern Rhodesia, the Poro in Sierra Leone, and other parts of West Africa also stood their ground against the British colonial imposition (Opoku 1985, 514, 516) and against attempts to re-invent and instrumentalize them. In his classic Things Fall Apart, Chinua Achebe holds colonial rule and the missionary societies accountable for the invasion of Igbo culture in Eastern Nigeria and the subjugation of the people. Prior to this, all novels that were written about Africa and Africans were by Europeans. In most cases they misrepresented Africans as uncivilized and uneducated (Kenalemang 2013, 4).

Like the colonial administrators, missionary representation of cultural institutions in Africa was negative. In several instances, these cultural institutions collaborated with the missionaries, but in most instances their relationship was cat-and-mouse-like. The missionaries, in very critical moments, relied on traders for funds and on the administration for physical protection and security. Some missionaries cooperated with colonial officials to exploit and culturally subjugate the Africans (Okon 2014, 198-199). There was also collaboration between the church and local leaders of different communities. For example, in the $1840 \mathrm{~s}$ in Old Calabar, the Efik Kings invited the Presbyterian missionaries into their communities and used the Ekpe to call people to church services. They wanted their children to become literate so that they would be able to keep the books and increase trading opportunities (Miller and Ojong 2012, 10). This romance did not last long because the church and Efik leaders soon ran into problems, and this was the beginning of the rift between the church and the indigenous leaders.

Missionary activities in Africa generally witnessed protests that were generated against mission policies and attitudes (Strayer 1976, 1). This is because, from the very beginning, missionaries expressed an uncompromising attitude towards African religions. They taught their converts that life could be separated into spiritual and secular spheres, a teaching in conflict with the fundamental basis of African culture which stressed the unity of religion and life (Opoku 1985, 513; Tshibangu 1993, 501). The degree of brainwashing and misrepresentation of the African concept of culture and religion is captured in this quotation from Opoku: 
The missionaries had a negative attitude towards African religion and culture and were determined right from the start to stamp them out. The missionaries preached that the only God was the one whose nature and character had been revealed in the Bible, and that all other gods were mere illusions; that the Son of God, Jesus Christ, was the final revelation and the only Saviour of mankind, and that the Church was the sole dispenser of divine grace and that there was no salvation outside the Church. They preached against all kinds of traditional practices - the pouring of libation, holding state offices, drumming and dancing, traditional ceremonies of the rites of passage, such as out-doorings, girls' puberty rites and customs associated with deaths and burials (Opoku 1985, 526).

At the start of their administration in Kom, Cameroon, the British did not interfere with the functions of the Kwifon regulatory institution. Rather, they saw in this institution a useful partner to strengthen the authority of the Fon and the elders over the people for easy administration. Barely a few years afterwards, that is in the 1930s, this partnership gave way to scepticism. The British argued that the Kwifon was too secretive and should no longer play an important role in the NA (De Vries 1998, 22-23).

The missionaries were either in conflict with other indigenous Cameroonian groups for misrepresenting them, or reacting to the peoples' blending of traditional institutions with church values. In Bakunduland, missionary expectations for the people were contrary to their way of life. The people simply blended Western and African values and made a mockery of the Basel missionaries' philosophy of evangelization (Ebune 2012, 48). Similarly, the Basel Mission encountered difficulties in Ndom, Bakossiland. The Reverend Pastor Otto Ebomtene Eseh refused to conduct church services and serve communion because the Christians celebrated Ndie. This is an annual ritual that is held at a particular place and is at the heart of the religious practices of the Bakossi people. Tension mounted and the people told the pastor that not everyone attended the Ndie ceremony (Ejedepang-Koge 2013, 430). The pastor failed to understand that the people's worship of God was through this annual ritual even before the advent of Christianity. In spite of the misrepresentation and conflicts between the missionaries and colonial administrators, the cultural institutions of the Cross River Basin played important and complementary roles.

\section{Roles of Ekpe, Obasinjom and Nfam}

British administrators and missionaries painted the cultural institutions of the Cross River Basin negatively in their activities and pronouncements. Prior to colonial rule, these were life sustaining institutions. The Ekpe performed governing, executive, judicial, religious, and knowledge dissemination functions. This institution also settled credit matters among trading communities and 
between communities and European merchants. (Leib and Romano 1984, 48; Röschenthaler 2006, 76; Kah 2008, 12; Nwokeji 2010, 6, 77; Röschenthaler 2011, 15-16; Fenton 2012, 36; Miller and Ojong 2012, 1; Agbor 2013, 47; Enoh 2013, 200; Enor 2015, 497; Hales 2015, 7). The Ekpe also served a social function for the people of the Cross River Basin and beyond. Among the neighboring Bakundu people, women requested help from the Ekpe to conceive and procreate. Hunters solicited assistance from the Ekpe for successful hunting expeditions. It also regulated the extraction of forest resources. The Ekpe supervised community projects like the construction of halls, clearing and cleaning of village roads, and supplying water. Defaulters paid the price of failing to collaborate. Today the right to own and build on land among the Efik, Efut, and Qua still requires the permission of the Ekpe. It is clear that the Ekpe is still locally powerful (Ardener 2002, 57, 214; Fenton 2012, 37; Jimoh et al. 2012, 212).

Social responsibilities were also one of the hallmark activities of the Ekpe. The institution upheld respect for the norms of marriage and sex in the past. The fear of being a victim of an Ekpe spell prevented young people from indulging in premarital sex. They grew up and properly negotiated marriage with their partners; then they brought forth responsible children (Egbe 2014, 56). As a social and economic duty, the Ekpe provided security and solidarity to migrating groups from the earliest times of their dispersions through the forested and riverine areas. The institution also conferred full citizenship on its members with titles. These people could make decisions with implications for the entire community. In addition, the Ekpe entertained the population with dance, music, and body mask performances. Such performances, like the Ngondo festivities in Douala, had the potential to "forge ethnic identity by emphasizing a united history, combined objectives for the future and a shared language and culture" (Röschenthaler 2010). The Ekpe were also a school for esoteric values of human life as a cyclic process of regeneration and the eventual reincarnation of a being.

Research discloses that even in the contemporary Cross River State of Nigeria, the Ekpe have effectively handled conflicts and communal clashes among kinsmen in those communities with a strong Ekpe presence. The Ekpe have prevented the wanton exploitation of forests in Cameroon by logging companies through its sanctions. The institution stresses integrity, recognition, and acceptance of members within their immediate communities and beyond through responsible behavior. It was/is the responsibility of the Ekpe to provide a social safety net for redistributing the wealth of richer members through the buying of titles and providing entertainment in food, music, and dance to amuse the community. The entertainment also exposes, enacts, and reemphasizes the cultural values and social norms of the community (Miller and Ojong 2012, 1-2, 6-9).

Apart from playing an important stabilizing role within the communities of the Cross River region and beyond, the Ekpe were also useful in spreading 
the Christian gospel at the beginning and protecting the business interests of Europeans traders. Since the Ekpe were considered a "tribal institution" whose laws were valid in all Efik communities, the missionaries used it to proselytize the area (Röschenthaler 2011, 117). Meanwhile, membership in the Ekpe came with benefits for European traders. Credit given to indigenous traders was recovered with the assistance of the Ekpe who confined a debtor to their home until the debt was paid. In extreme cases, the debtor was sold together with his property and slaves (ibid., 118). The protection that the Ekpe offered encouraged European traders to buy titles in these societies and to sit and drink with the Ekpe chiefs. The institution also assisted its members in trading slaves, during the slave trade epoch, and other trade items by protecting trading routes and providing travelers with free food and lodging.

In all these ways, the Ekpe contributed to regulating trade (Miller 2011, 287; Röschenthaler 2011, 125; Kah 2013, 31). In fact, in Calabar, Nigeria, the Ekpe have continued to play this economically relevant function of being a source of revenue for its members and also a mechanism through which they demonstrate status, wealth, and power through performative displays (Hales 2015, 64). This is similarly the trend in Cameroon. Politicians join the Ekpe to make themselves relevant and gain support from the people. An example of this was the enthronement on April 15, 1979 of the then Minister of State for Post and Telecommunications Emmanuel Tabi Egbe as the Chief of Egbe's Ekpe house in his village of Bachou Akagbe in the Cross River Basin (ibid.). This episode made him think that he was more relevant to his people and he used it for political leadership in Manyu Division of the South West Region of Cameroon.

Besides the Ekpe, the Obasinjom and Nfam institutions have played significant roles in the propagation of the culture and traditions of the people of the Cross River Basin and beyond. The Nfam (also Afam or Mfam) was used in the adjudication of cases over farmland, death of an individual in doubtful circumstances, or cause of crop failure. Suspects swore by the herbs and other forms of traditional medicine presented by the Nfam to either prove their innocence or guilt. The Nfam was usually recognizable by two horns filled with a concoction of herbs and other material (Röschenthaler 2011, 19). Following a dispute over a piece of land between two villages, the Nfam medicines were brought and elders of the two villages involved swore by it. Those who refused to swear were considered guilty. Swearing by Nfam medicines prevented people from telling lies. The Nfam checked the activities of witches and sorcerers and punished misdeeds (Kah 2008, 16-17). The Nfam was a complementary institution to the Ekpe. The use of the Nfam was not limited to the Cross River Basin of Cameroon. In the 1920s, this institution was exported to other coastal regions of Cameroon by the Banyangi people of the Cross River region (Lee 2012, 583). This was to adjudicate cases between their kith and kin and other ethnic groups. The important role of the Nfam, like the Obasinjom and Ekpe, is coveted 
today by the Cameroonian intellectual and political classes seeking empowerment in the Freemason foreign cult (Neba 2014, 264).

Similarly, the Obasinjom worked to rid communities of wrong doing, especially witchcraft. Among the Ejagham, its members often gathered to offer sacrifices of food to God. During the annual ritual ceremony, newly initiated members brought food items like chicken, meat, eggs, and calabashes of palm wine for entertainment. Hunters called on the Obasinjom and pleaded for good luck in their activities. In fact, the Obasinjom served essentially a dual purpose: socialization and the promotion of peace and harmony in the communities along the Cameroon-Nigeria border (Kah 2008, 17; Kah 2013, 29). This important function of the Obasinjom inspired Neba $(2014,271)$ to opine that resorting to it and other related institutions is "a process of intellectual and political circumcision, rejuvenation and empowerment." The Obasinjom were reputed in the identification of witches and wizards and in stripping them of evil (ibid., 265). Following wealth accumulation in Bakweriland and accusations of witchcraft in the 1950s, the people borrowed Obasinjom from the Banyang to solve the problem (Nyamnjoh 2005, 242; Lee 2012, 583).

\section{Misrepresentations of These Institutions}

In spite of the immense utility of these institutions, as highlighted above, colonial administrators and missionaries described them in all sorts of (misrepresentative) appellations. Kah $(2008,13)$ captures vividly this misrepresentation saying that:

It was due to ignorance or a deliberate attempt by the Germans and British, for example, to describe the religious practices of the different ethnic groups of Mamfe Division as primitive and retrogressive. They also argued, incorrectly so, that these people were worshippers of spirits like Obasinjom and the ancestors. In some cases, the people were described as worshippers of stones, shrines and trees. This belief gave the impression that the people of Mamfe Division were "pagans" or heathens... were considered as good for nothing institutions and the colonial officials derogatorily described them as "food consuming" societies. In addition, they were also seen to be involved in the invocation of spirits, inciting highway robbery, among other unacceptable things in the eyes of the colonial agents.

Worship in traditional African communities is centered on a blend between the physical and human environment and so involves the use of shrines, stones, trees, and food. This should, therefore, not have been described by the Germans and British colonial officials as primitive and retrogressive.

It was rather unfortunate that a people's governing and regulatory institutions would be described in such pejorative terms as to discard them completely. The representation of the Ekpe as a primitive institution is also discussed by Miller 
and Ojong $(2012,1)$. The activities of such institutions became occasionally useful when these were used to advance British colonial interests in this region of Cameroon. The structures erected in Bakunduland to house the Ekpe instruments were described by visiting European officials as "idol houses" (Ardener 2002, 214). This invariably meant the people were idol worshippers. Yet the erection of the statute of Mary and Christ by the missionaries was not considered by the missionaries as idols. This negative categorization of the Ekpe was started in the early period by merchants, and then was continued by missionaries and colonial officials to the present where literate individuals have "caricatured [the Ekpe] as witchcraft and superstition" (Ajibola 2014, 4-6). Also, since the Ekpe society restricted membership, it led to the misunderstanding that it worshipped a bush or leopard-like spirit (Fenton 2012, 37).

Misrepresentation of the Ekpe spanned from the colonial to the postindependence era. The colonial authorities saw in the chief of the Ekpe an autocrat, not knowing that decisions were made by consensus among the leaders, which can be classified as a consensual democracy. Prior to German and British rule, the chief of the Ekpe was highly respected and not feared. The colonial authorities gave the impression that the chief of the Ekpe acted without consultation with other Ekpe leaders. The activities of the Ekpe were centered mostly on improving the welfare of the people (Enoh 2013, 200), and needed the approval of its members before decisions were finalized. The institution was so debased after independence that it needed real resuscitation to the status of the precolonial past. Colonial laws and global communications have negatively impacted its ancient practices of collective decision making. Besides, government agencies concerned with the promotion of tourism portray Ekpe instruments as mere ornaments of folklore and tourism. The masquerade performances which inculcated and promoted harmony and cordiality have become less important. The colonial officers regarded the Ekpe as a political problem rather than part of a solution.

There have been misrepresentation and allegations levied against these cultural institutions. Around Kumba in 1889, for example, cultural institutions were banned by German colonial officials. Later on in the 1940s, educated Christian elites levied scathing criticisms against cultural institutions. According to them, these institutions were used by the families of the deceased to demand money, and they also discouraged education (Röschenthaler 2011, 126). The educated elite seemed to have been blind to the fact that the promotion of Western education was a disservice to indigenous education. If they were conscious of this, they would not have sought to debunk these important cultural institutions. The Ekpe actually developed the Nsibidi language many years before the advent of Western education. This language would have developed to become more useful to the people had Western education not undermined it. Similarly, Partridge (1905) argued that the Ekpe was a bad institution because a 
group of people could gang up against one person and ruin him. The tendency to "incarcerate" Ekpe members is partly a result of the image painted of it in the colonial period by administrators and missionaries (Miller and Ojong 2012, 11, 13; Ganyi et al. 2013, 56).

Missionaries also painted a bleak picture of these cultural institutions. They described the Ekpe as things of the devil and as fetishes (Röschenthaler 2011, xxiv). The London Mill Hill missionaries said that Christian settlements should be independent of the local chiefs. Their clergy encouraged people to rebel against tradition and the cultural institutions that propagated tradition (Kah 2008, 24). The Basel missionaries at one point restrained the Mbo, Bangwa, and Mundane ethnic groups from the free practice of their traditions and customs. This was, however, not done in all places in the Cross River region and its hinterlands. In 1923, a Duala head preacher of the Protestant mission in Besongabang and Ossing condemned husbands of some Christian women because they had asked their wives to "swear by the Nfam religious cult which opposed the Christian doctrine." The village council had asked everyone to swear by the Nfam medicines (ibid., 25). Meanwhile the Basel Mission in Ejagham and Banyang villages complained of the inability of its missionaries to preach the gospel because "entire villages" migrated to sell "gods" to neighboring groups (Röschenthaler 2011, xxiv). This implies that the people had faith and propagated the Ekpe institution in neighboring villages instead of listening to an alien and irrelevant gospel.

Although there was a strong disregard for these cultural institutions, the British occasionally used some in the administration of justice. They used the Nfam, for example, to adjudicate cases in the Native Courts in Mamfe Division. There were, however, reports that all Christians who swore by it lost all the cases and suffered great personal losses. This should not be taken very seriously because it paints a negative picture of the Nfam. While the administration allowed the use of Nfam for judicial purposes in Mamfe Division, this was not done in all places because in the Kembong area there were problems and the administration warned against its use. The Kembong Native Court considered the actions of the Nfam to be criminal (Kah 2008, 26).

In Calabar, like other parts of the Cross River Basin of Cameroon and Nigeria, early missionaries contested the authority of the Ekpe. Through the media and propagandist sermons in the churches, the Ekpe are also demonized today. The Ekpe form of prayer through goat and chicken blood has been described as superstitious and heathen (Fenton 2012, 70). This is rather awkward because the Christian churches from the colonial era had the contestable impression that there was a prescribed way of worshipping God and those who did not adhere to it were non-conformists who were doomed to eternal damnation. The Ekpe members, however, fought back against the desecration of their respectable institution. In one such instance in 1856 before British rule, the mission house in Duke Town, Calabar was completely severed from the 
community. The missionaries were asked to leave and were only saved through the intervention of the British (ibid., 72). The situation is, however, changing as within the Ekpe houses certain issues are openly debated for eventual reform (ibid., 73). If today cultural institutions like the Obasinjom and Ekpe are described in terms of mythologies, it is because of the opaque image they were given in the colonial era (Neba 2014, 260). The attack on them in the colonial era did not, however, prevent their spread to other areas.

\section{Continuous Spread and Relevance}

The origins of the Ekpe can be traced to the Balondo or Efut speaking region of the Cross River region of Cameroon before the colonial period, and it spread to the Efik and Ejagham who popularized and instrumentalized it. It then spread further afield into the hinterlands regions of Cameroon and Nigeria within the context of trade relationships (Miller 2012, 86). The Isangele integrated the hinterland villages into the Ekpe and this enlarged its trading sphere. Through this, the Isangele organized raids without military domination and state-like infrastructure. When the Efik acquired the institution from the Balondo, they introduced it to the Ejagham villages (Röschenthaler 2011, 95). While European traders, missionaries, and colonial administrators used or discarded the Ekpe, it accommodated these new cultural practices and continued to spread to other lands. The spread of the Ekpe, Obasinjom, and Nfam far afield from their areas of origin did not start nor end with the advent of colonial rule in the Cross River region of Cameroon and Nigeria. This was both a manifestation of cultural resilience and their continuous relevance.

When the Ekpe started in the Cross River region, it began to spread to other areas after the Efut, Efik, and Ejagham ethnic groups were the first to appropriate it from its source region. Röschenthaler $(2006,76)$ argues that Ekpe, a men's graded leopard society, started specifically among the Isangele of Ndian Division of Cameroon in the Bakassi Peninsula which divides Cameroon and Nigeria. It was the Isangele people who sold this graded leopard society to the hinterland communities and also the Efik of Calabar, an important trading center in the Bight of Biafra. The Efik appropriated the society, introduced more grades, and exported it. The exportation or dissemination of Ekpe was not the sole prerogative of the Efik. Other groups that acquired the Ekpe also exported it to their neighbors. These included the Ejagham and Banyang. Other ethnic groups also acquired the Ekpe from the Isangele people and added their own contributions to make the Ekpe a truly multi-ethnic institution with assimilationist tendencies (Miller 2005, 13; Miller and Ojong 2012, 10). Among the reasons advanced by Röschenthaler and other writers for its spread (Miller 2005, 12) is its use as a governing institution by the villages that acquired it. The Ekpe also facilitated 
trade, especially slave trade, prior to colonial rule, and trade in other commodities like palm oil when the slave trade declined. The institution was also popular among the acquiring communities because of its masquerade dances. It was a judicial institution and debts of members were collected through it. Initiated members paid an initiation fee including those who ascended to higher grades within the institution. Today, the Ekpe operates in hundreds of communities having a common set of values and symbols among which are truth and justice.

The Ekpe became a regional institution beyond Cameroon and Nigeria. Through trade it was exported to neighboring Equatorial Guinea. In the late nineteenth century, people with knowledge of the Ekpe from both the Cross River region and Cuba were transported to Malabo in Equatorial Guinea as political exiles and plantation workers. They gathered there and instituted a genre of Ekpe called Bonko. This name is consistent with the Ekpe grade of Ebongo, or Ebonko, found in both West Africa and Cuba (Miller and Ojong 2012, 5). Considering the spread of the Ekpe institution to other areas from its core region of the Cross River Basin, in 2000 at the Calabar International Ekpe Festival, participants emphasized the need to bring all Ekpe communities together from Nigeria, Cameroon, Equatorial Guinea, and Cuba (Ajibola 2014, 4-6). The Abakua institution in Cuba from the Cross River Basin has become a mutual-aid society for its members (Miller 2012, 85), and the exchange of ideas between the Ekpe branches can help revitalize this important cultural institution. The calls for unity among all branches should, however, be taken with a grain of salt because of the difficulties of geographical separation and diverse political environments. Politicians are likely to hijack it for greedy ends. Effective coordination might be difficult because of distance and different local realities. The ones in Latin America and the United States can work together due to geographical proximity and the ones in Cameroon, Nigeria, and Equatorial Guinea can do same.

The spread of the Ekpe did not end in Cameroon, Nigeria, and Equatorial Guinea, and it also spread to Latin America in Cuba, Argentina, Uruguay, El Salvador, the Rio regions in Brazil, and some parts of the United States, notably the Sea-Islands of South Carolina and Georgia where people of slave origin can trace their origin to the Cross River Basin. The Abakua is an important institution that has united the people of Latin America and their brethren of the Banyang and Ejagham (Miller 2005; 2011, 2012; Miller and Ojong 2012, 7; Enoh 2013, 206). Evidence from Cuba where the Ekpe offshoot Abakua started around the mid-1830s shows that Calabar or Balondo of Southwestern Cameroon may have been the original home of Ekpe (Nwokeji 2010, 78). This argument is echoed by Röschenthaler (2011) who emphasizes Balondo or Efut origin.

Within Cameroon, the Ekpe was and still functions in areas which acquired it a long time ago. Among these ethnic groups are the Ejagham, Banyang, Anyang, Boki, Assumbo, and Obang-Balundu (Kah 2008, 15). The spread of Ekpe also extended to territory in present day French speaking Cameroon, namely Batanga. 
Through trading networks, the Bangwa of Fontem acquired it and it spread also to the grassfields region of Cameroon (Miller and Ojong 2012, 5). For the Nfam, apart from Kembong and Besongabang villages among many other Ejagham and Banyang villages, it was also acquired by the Bakundu villages among which were Kombone and Marumba in the Kumba neighborhood and the Balue village of Betene. The price for acquiring the Nfam juju during British rule was \& GBP 15, as reported by a British colonial officer (Röschenthaler 2011, xxiv). Apart from its spread to the forest region of Cameroon, the Nfam was joyously acquired by the elders of the Ambele, Moghamo, and Meta ethnic groups located in the northern parts of the Mamfe Division and parts of the Bamenda Division (Kah 2008, 16). They appreciated it because people swore by its medicines to prove their innocence or guilt.

The Ekpe is one of the most widespread of all the cultural institutions in the Cross River region of Cameroon and Nigeria. In the Isangele village groups, including the Balundu, Oroko (Bima, Batanga, Bakoko), Northern Balong, Ngolo, and Korup villages (including Okoyong), the institution became the mostimportant law enforcing institution. In all of the Ejagham, Banyang, Boki, Ikom, Akparabong, Okuni, Anyang, and Manta villages, the Ekpe was the governing institution. The institution also spread as far north as the Atolo, Matene, Basho, Menka, and Mbulu villages (Röschenthaler 2011, 120), showing its relevance and popularity among the people.

Apart from the Northwest of the Cross River's hinterlands, the Ekpe network extended to Widekum, an important trading nodal point between the grasslands and forest regions of Cameroon. To the Southeast, East, and Northeast, Mbonge, Bakundu, Bassosi, Bafaw, Western Mbo, Bitieku, Ambele, Befang, Otutu, and other communities up to Numba came under the Ekpe network. This sometimes led to conflict in some communities. In Bassosiland, for instance, there was a clash between the Muankum and Ekpe as both served as law-enforcing societies (ibid., 121). The geographic spread and influence of the Ekpe and Nfam in the Cross River Basin and beyond was an indication of how the people identified with it to address their immediate socio-cultural, economic, and political problems. The spread had started before German and British rule in the area and continued during and after their era of administration. This was against a background of mistranslation and interpretation of the relevance of these institutions to their people.

\section{Conclusion}

The deliberate misinformation, misrepresentation, misinterpretation, and misdescription of African cultural institutions by the colonial administrators and missionaries, and the choice of words to describe some of their institutions 
and activities, fall within the realm of translation, considered in this article as historical (mis)translation. After situating the article within this conceptual framework, we examined the importance and uses of cultural institutions to Africans from time immemorial and their importance, which has continued to make many people join them and adhere to their principles even as Christians. They blend Western and indigenous values to show how important and relevant these institutions are within the modern systems of administration.

The Ekpe, Obasinjom, and Nfam cultural institutions were debased, misused, and misinterpreted by the British colonial administrators who worked in the Cross River Basin of Nigeria and Cameroon. This unfortunately led in some cases to scuffles and a strain in relations between indigenous institutions and the British representatives in the area. It has been shown that in spite of the deliberate, ridiculous descriptions of the true relevance of these important cultural institutions, some of them continued to spread to other areas of the Cross River Basin and beyond. The institutions served a very useful purpose in the socio-political and, in some cases, economic life of the people and European merchants. This explains why, in spite of the crack down on them, they blossomed in the colonial period. It should, however, be understood that continuous attacks on these cultural institutions have negatively impacted some of their activities, but these institutions, especially the Ekpe, live on and are unlikely to phase out in the foreseeable future. Politicians seeking relevance to their people have joined the Ekpe, if for nothing else, to become relevant in national politics.

This study, therefore, suggests there is need for in-depth studies on the continuing relevance of African cultural institutions in the face of the negative impact of global interaction and communications. There is also a need for greater research on colonial misrepresentation of cultural institutions and its instrumentalization. The use of phrases to describe African institutions needs further study from a comparative basis between Africa, Asia, and Latin America. This study is an argument in this direction and other such studies of historical mistranslation in other parts of Cameroon and Africa would be commendable.

\section{References}

Abu-Mahfouz, Ahmad. 2008. “Translation as a Blending of Cultures." Journal of Translation 4 (1): $1-5$.

Afigbo, A.E. 1985. “The Social Repercussions of Colonial Rule: The New Social Structures.” In General History of Africa VII: Africa under Colonial Domination 1880-1935, ed. A. Adu Boahen, 487-507. Berkeley, CA: Heinemann.

Agbor, Tabetah Beckly. 2013. “The Perceptions/Views of Cameroon-Nigeria Bakassi Border Conflict by the Bakassi People." MA diss, Uppsala Universitet.

Ajibola, Augustus Babajide. 2014. "Nomination Form for Inclusion on UNESCO’s List of 
Intangible Cultural Heritage." Representative List ICH-02-2014-EN. March 13.

Ardener, Shirley, ed. 2002. Swedish Ventures in Cameroon 1883-1923: Trade and Travel, People and Politics, The Memoirs of Knut Knutson with Supporting Material. New York and London: Berghahn Books.

Austen, Ralph A. 1992. "Tradition, Invention and History: The Case of the Ngondo (Cameroun)." Cahiers d'Etudes Africaines 32 (126): 285-309.

Bartelt, Brian. 2006. "Healers and Witches in Oku: An Occult System of Knowledge in Northwest Cameroon." PhD diss., University of Southern California.

Cadwell, J.C. 1985. "The Social Repercussions of Colonial Rule: Demographic Aspects." In General History of Africa VII: Africa under Colonial Domination 1880-1935, ed. A. Adu Boahen, 458-486. Berkley, CA: Heinemann.

Chilver, E.M., and P.M. Kaberry. 1960. "From Tribute to Tax in a Tikar Chiefdom.” Africa: Journal of the International African Institute 30 (1): 1-19.

Connah, Graham. 2003. "Images of Africa." The Australasian Review of African Studies 25 (1): 26-37.

Crowder, Michael. 1993. "Africa under British and Belgian Domination, 1935-45." In General History of Africa VIII: Africa since 1935, eds. Ali A. Mazrui, and C. Wondji, 76-101. Berkley, CA: Heinemann.

De Vries, Jacqueline. 1998. "Catholic Mission, Colonial Government and Indigenous Response I Kom (Cameroon).” African Studies Centre Research Report 56, Leiden University. https://openaccess.leidenuniv.nl/handle/1887/485 (accessed on March 12, 2016).

DeKorne, Helen. 2012. "The Builders of Identity: Education, Language, and the Elites of Cameroon, 1916-1961.” B.A. Long Essay, Wesleyan University. http://wesscholar. wesleyan.edu/etd_hon_theses/844/ (accessed on April 14, 2016).

Ebune, Joseph Betoto. 2012. "Missionary Activity in Bakunduland, Cameroon, 1873-1960: An Historical Appraisal." Global Advanced Journal of History, Political Science and International Relations 1 (2): 48-55.

Egbe, Manfred. 2014. "Sexuality in the Bayang Community-Mamfe, South West Region of Cameroon." Arxiu d'Etnografia de Catalunya 14: 53-71.

Ejedepang-Koge, S.N. 2013. Know Yourself in the Service of People: My Roots-An Autobiography. United States: Xlibris.

Enoh, Richard Agbor Ayukndang. 2013. "Religion, Traditional Culture and Creolisation in the African Diaspora: The Case of the Banyang and Ejagham in the South West Region of Cameroon." Tropical Focus: The International Journal Series on Tropical Issues 14 (2): 199-208.

Enonchong, Dennis E. “Conversation Proposed Questionnaire." Unpublished Manuscript.

Enor, Frank N. 2015. "Pre-modern Systems of Punishment for Offences in Ikom Traditional Society, Cross River State, Nigeria." Journal of Social Sciences and Humanities 1 (5): 495-498.

Faiq, Said. 2008. "Cultural Misrepresentation through Translation.” Journal of Language and Translation 9 (2): 31-48.

Fenton, Jordan A. 2012. "Take it to the Streets: Performing Ekpe/Mgbe Power in Contemporary Calabar, Nigeria." PhD diss., University of Florida.

Ganyi, Francis Mowang, Idom T. Inyabri, and James O. Okpiliya. 2013. "Performance Aesthetics and Functionalism: The Legacy of Atam Masquerade of the Bakor People 
of Ogoja Local Government Area." International Journal of Humanities and Social Invention 2 (10): 50-62.

Hales, Kevin. 2015. "The Moving Finger: A Rhetorical, Grammatological and Afrinographic Exploration of Nsibidi in Nigeria and Cameroon." PhD diss., Ohio University.

House, Juliane. 2015. Translation Quality Assessment: Past and Present. New York: Routledge. Jimoh, Saka Oladunni, Emmanuel Tertsea Ikyaagba, Abiodun Alarape, Emeka E. Obioha and Adsoji Akinwumi Adeyemi. 2012. "The Role of Traditional Laws and Taboos in Wildlife Conservation in the Oban Hill Sector of Cross River National Park (CRNP), Nigeria." Journal of Human Ecology 39 (3): 209-219.

Kah, Henry Kam. 2008. "Religious Cults in Conflict with Colonial Forces, 1916-1961: Its Impact on the Social Life of Mamfe Division in British Southern Cameroons." Orita: Ibadan Journal of Religious Studies 40 (2): 11-32.

Kah, Henry Kam. 2011. "Regulatory Societies, Peacebuilding and Maintenance in the Cross River Region of Nigeria and Cameroon." African Conflict and Peacebuilding Review 1 (2): 50-73.

Kah, Henry Kam. 2013. "Sustained Interaction in a Disintegrated Cross-River Region Border of Cameroon and Nigeria." Global South 9 (3): 26-34.

Kah, Henry Kam. 2015. The Sacred Forest: Gender and Matriliny in the Laimbwe History (Cameroon), c. 1750-2001. Berlin: Lit Verlag.

Kenalemang, Lame Maatla. 2013. “Things Fall Apart: An Analysis of Pre and Post-Colonial Igbo Society." BA thesis, Karlstads Universitet.

Lee, Anthony A. 2012. "Underground Movement in a Missionary Church: The Baha'I Faith in British Cameroons, 1952-1962." Journal of Religious History 36 (4): 577-592.

Leib, Elliot, and Renee Romano. 1984. "Reign of the Leopard: Ngbe Ritual." African Arts 18 (1): 48-57.

Majuk, Simon E. 2011. “The Atam among Ogoja Bakor: An Adaptation of Ngbe (Leopard) Society in Southern Nigeria." Calabar Journal of Liberal Studies: An Interdisciplinary Journal 15 (1): 64-76.

Mbu, Arrey Ogem Pascal. 2013. "Chieftaincy, Development and Democratisation: A Case Study of the Banyang and Ejagham Ethnicities of Southwest Cameroon." MA diss., Central European University.

Miller, Ivor. 2005. "How I Went to Calabar and Became an Ekpe Ambassador to the Cuban Abakuá Brotherhood." WARA Newsletter, Spring, 11-13.

Miller, Ivor. 2011. "Faith: Abakuá Society." In Cuba: People Culture, History, ed. Alan WestDuran, 287-292. New York: Scribner World Scholar.

Miller, Ivor L. 2012. "Bongo Ita: Leopard Society Music and Language in West Africa, Western Cuba and New York City." African and Black Diaspora: An International Journal 5 (1): 85-103.

Miller, Ivor, and Mathew Ojong. 2012. "Ekpe 'Leopard' Society in Africa and the Americas: Influence and Values of an Ancient Tradition." Ethnic and Racial Studies 36 (2): 266281.

Mokake, Flavius M. 2012. "Social Peace and the Ngondo Traditional Festival of the Duala of Cameroon." African Conflict and Peacebuilding Review 2 (2): 88-103.

Mungwini, Pascah. 2011. "Philosophy and Tradition in Africa:' Critical Reflections on the Power and Vestiges of Colonial Nomenclature." Thought and Practice: A Journal of the Philosophical Association of Kenya (PAK) New Series 3 (1): 1-19. 
Neba, Divine Che. 2014. "Mythologising Post (Coloniality) in Cameroon Poetry: The Case Study of Bate Besong's Disgrace, Autobiographical Narcisus and the Emanya-Nkpe Collected Poems." Academic Research International 5 (6): 260-272.

Nwokeji, G. Ugo. 2010. The Slave Trade and Culture in the Bight of Biafra: An African Society in the Atlantic World. Cambridge: Cambridge University Press.

Nyamnjoh, Francis B. 2005. "Images of Nyongo amongst Bamenda Grassfielders in Whiteman Kontri." Citizenship Studies 9 (3): 241-269.

Okon, Etim E. 2014. "Christian Missions and Colonial Rule in Africa: Objective and Contemporary Analysis." European Scientific Journal 10 (17): 192-209.

Opoku, K. Asare. 1985. "Religion in Africa during the Colonial Era." In General History of Africa VII: Africa under Colonial Domination 1880-1935, edited by A. Adu Boahen, 508-538. Berkley, CA: Heinemann.

Partridge, Charles. 1905. Cross River Natives: Being Some Notes on the Primitive Pagans of Obubura Hill District, Southern Nigeria. London: Hutchinson and Co.

Ranger, Terence. 1992. "The Invention of Tradition in Colonial Africa." In The Invention of Tradition, eds. Eric Hobsbaum and Terence Ranger, 211-262. Cambridge: Cambridge University Press.

Röschenthaler, Ute M. 2006. “Translocal Cultures: The Slave Trade and Cultural Transfer in the Cross River Region.” Social Anthropology 14 (1): 71-91.

Röschenthaler, Ute. 2010. “'Celebrating our Heritage’: Lokale Festivals, Erinnerungskultur und neue Identitäten in Kamerun und Nigeria." Johannes Gutenberg Universität Mainz, Department of Anthropology and African Studies, Working Paper Nr. 118.

Röschenthaler, Ute. 2011. Purchasing Culture: The Dissemination of Associations in the Cross River Region of Cameroon and Nigeria. New Jersey: The Africa World Press.

Simour, Lhoussain. 2014. Recollecting History beyond Borders: Captives, Acrobats, Dancers and the Moroccan-American Narrative of Encounters. Cambridge: Cambridge Scholars.

Strayer, Robert. 1976. "Mission History in Africa: New Perspectives on an Encounter." African Studies Review 19 (1): 1-15.

Talbot, P. Amaury. 1912. In the Shadow of the Bush. London: William Heinemann.

Tshibangu, Tshishiku. "Religion and Social Evolution." In General History of Africa VIII: Africa since 1935, ed. Ali A. Mazrui and C. Wondji, 501-521. Berkley, CA: Heinemann.

Venuti, Lawrence. 1995. The Translator's Invisibility: A History of Translation. London: Routledge.

\footnotetext{
Henry Kam Kah is an Associate Professor of History at the University of Buea in Cameroon. His research interests include gender, conflict, security, and culture. His most recent publication is "Boko Haram is Losing, but so is Food Production: Conflict and Food Insecurity in Nigeria and Cameroon." Email: henry.kah@ubuea.cm; ndangso@yahoo.com
} 
